\title{
ETNOMEDIK PADA MASYARAKAT BUGIS
}

\author{
Oleh \\ ${ }^{1}$ Shermina Oruh ; shoruh68@gmail.com \\ ${ }^{2}$ Andi Agustang; andi.agustang@unm.ac.id
}

\section{Pendahuluan}

Tema etnomedik dewasa ini mulai diperbincangkan khususnya kalangan profesional kesehatan oleh karena berkembangnya kesadaran faktual tentang perilaku pencarian pengobatan masyarakat yang masih mencerminkan praktek berbasis nilai-nilai lokal sebagai legacy secara turun temurun. Pengaruh unsur-unsur budaya yang melekatdan hidup serta terus tumbuh dalam dunia kesehatan mengindikasikan perlunya pembacaan ulang terhadap pendekatan medis yang selama ini cenderung mendominasi pelayanan kesehatan, khususnya pelayanan kesehatan kuratif dan rehabilitatif (A. Agustang \& Oruh, 2017)

Perspektif fundamental yang dapat dijadikan sebagai paradigma dalam membaca ulang dominasi pendekatan medik dalam dunia kesehatan adalah perspektif etnomedik. Perspektif ini merupakan aliran pemikiran yang berupaya untuk mendamaikan praktek pengobatan tradisional yang berbasis budaya dan nilai lokal dengan praktek pengobatan modern yang berlandaskan pemanfaatan ilmu pengetahuan dan teknologi kesehatan (Asri et al., 2019) Pemikiran jalan tengah ini semakin menemukan relevansinya dalam kancah pembangunan manusia Indonesia yang mengedepankan pendekatan partisipatoris dimana pendekatan ini menghendaki adanya adaptasi program pembangunan dengan artefak sosial budaya masyarakat yang dipedomani dalam berkehidupan sehari-hari (A Agustang, 2021).

Saya ingin mendefinisikan secara sederhana tentang perspektif ini sebelum menguraikan lebih jauh tentang penerapannya pada konteks kultur masyarakat bugis. Etnomedik adalah praktek pengobatan yang mencerminkan pengaruh unsurunsur budaya terhadap penghayatan masyarakat tentang penyakit dan kesehatan (Andi Agustang \& Oruh, 2021). Penekanan definisi ini terletak pada cara masyarakat mempersepsikan gejala sakit dan penyakit yang dihadapi mendeterminasi cara masyarakat dalam pengobatannya. Ini berarti pula bahwa fokus penelahaan terletak pada konsep sehat-sakit masyarakat.

Pembentukan konsep sehat-sakit masyarakat dipengaruhi oleh persepsi, keyakinan, kepercayaan, pengalaman, dan pengetahuan yang berakumulasi menjadi penafsiran/interpretasi/ atau penilaiannya terhadap penyakit tertentu. Banyaknya kompartemen pembentukan konsep sehat-sakit menggambarkan bahwa penerapan pendekatan etnomedik mensyaratkan keterlibatan multidisiplin dengan proses yang bersifat long term, mulai penelahaan masalahnya sampai pada metode eksekusinya di lapangan.

Kehadiran pendekatan etnomedik dalam pembangunan kesehatan terasa menjadi oase yang cukup menyejukkan dalam padang pasir kegersangan pembangunan kesehatan yang monoton dan membutuhkan terobosan-terobosan inovatif, inspiratif, dan replikatif. 
Muncul pengharapan yang besar lahirnya perubahan-perubahan signifikan terhadap indicator-indikator pembangunan kesehatan yang lebih baik dengan menerapkan teknik-teknik baru dalam proses pelayanan kesehatan di masyarakat. Harapan ini tentulah manusiawi mengingat beberapa indicator pembangunan kesehatan di Indonesia belum mencapai target (off target) seperti usia harapan hidup yang masih mangkrak di kisaran angka 69 tahun, jumlah anak yang mengalami stunting masih sangat tinggi yang mencerminkan upaya perbaikan gizi belum optimal, dan angka kematian ibu serta anak sepertinya belum mengalami kecenderungan statistik yang menurun dari waktu ke waktu. Padahal sumber daya yang sudah dikeluarkan untuk mengentaskan persoalan kesehatan seperti ini tak terhitung jumlahnya (Oruh, 2021).

Oleh karena itu, pendekatan etnomedik menurut Saya menjadi alternatif solusi dalam memperbaiki kelemahan dan keterbatasan program-program pembangunan kesehatan yang boleh jadi merupakan pangkal penyebab terjadinya involusi pembangunan kesehatan di Indonesia.

\section{Justifikasi Empiris}

Etnomedik dalam posisinya sebagai pemikiran antithesis dan alternative solusi tentu akan menciptakan pertentangan konseptual dan ketegangan-ketegangan sosial terutama bagi para penganut konservatisme medis modern yang selama ini dominan. Dibutuhkan suatu justifikasi empiris dalam memahami pendekatan etnomedik ini secara utuh agar membuka wawasan bagi semua pihak dalam menerima pendekatan ini sebagai sarana percepatan pembangunan kesehatan di Indonesia.

Setidaknya ada 4 alasan yang Saya identifikasi sebagai justifikasi empiris dalam memandang pentingnya pendekatan etnomedik diinternalisasi dalam anatomi/postur pelayanan kesehatan di Indonesia.

Pertama, paradigma pembangunan nasional menggunakan paradigma people centred yang menghendaki pembangunan manusia sebagai fokus intervensi oleh semua sektor, baik pemerintah, swasta, maupun masyarakat. Keberhasilan pembangunan sumber daya manusia diukur menurut indeks pendidikan, kesehatan, dan tingkat kesejahteraan penduduk. Ini berarti bahwa kesehatan merupakan salah satu pilar yang menopang pembentukan SDM yang unggul. Implikasinya, membicarakan kesehatan tidak bisa dilepaskan dari pembicaraan tentang manusia, baik sebagai individu maupun sebagai masyarakat.

Pembangunan kesehatan yang konsonan dengan pembangunan nasional pasti mendapatkan aliran sumber daya pembangunan yang memadai. Ujungnya, segala permasalahan yang menghambat laju pembangunan kesehatan dapat dikelola dengan baik, sehingga status dan derajat kesehatan masyarakat berangsur-angsur ditingkatkan pada level yang lebih layak dan menyakinkan.

Kedua, lahirnya kebijakan desentralisasi pembangunan kesehatan menghendaki terbukanya otonomi seluas-luasnya bagi daerah untuk merancang bangun postur pembangunan kesehatan daerah yang dikehendakinya. Sprit kebijakan desentralisasi pembangunan kesehatan menginginkan keseluruhan ciri dan pendekatan program- 
program kesehatan hendaknya mempertimbangkan karakter spesifik-lokal yang dimiliki oleh daerah masing-masing.

Karakter lokalitas yang mewarnai pembangunan kesehatan di daerah sesungguhnya mengandung makna bahwa determinan masalah kesehatan yang terjadi berasal dari dimensi sosial-budaya masyarakat. Rentetan peristiwa dan pengalaman dapat dijadikan sebagai evidence dalam memahami dimensi sosial-budaya sebagai pencetus masalah kesehatan sekaligus sebagai trigger efektif dalam pengendaliannya. Katakanlah, pengendalian penyakit TBC yang masih terkendala oleh kepercayaan terhadap mitos menyebabkan masyarakat memiliki kekhwatiran, dan ketakutan, bahkan kepanikan. Hal serupa digambarkan juga pada kejadian penyakit menular lainnya seperti kusta, IMS, HIV dan AIDS (Andi Agustang, 2021a).

Ketiga, kesadaran akan pentingnya individu dan masyarakat dalam pembangunan kesehatan mendorong lahirnya gerakan-gerakan pembangunan kesehatan yang memosisikan masyarakat sebagai mainstream, seperti Gerakan Masyarakat Hidup Sehat (Germas), Program Indonesia Sehat Pendekatan Keluarga (PIS-PK), Program Nasional Kampung KB, Sanitasi Total Berbasis Masyarakat, pembentukan kader pembangunan manusia (KPM) dan sejumlah program-program kesehatan yang memberi titik tumpuh terhadap kekuatan yang dimiliki oleh masyarakat dan desa.

Mainstreaming program kesehatan tersebut diimplementasikan melalui upaya pemberdayaan masyarakat untuk mendorong munculnya kemauan dan kemampuan masyarakat dalam menerapkan perilaku hidup sehat. Upaya pemberdayaan masyarakat hanyalah berhasil jika menggunakan perangkat sosial-budaya sebagai peralatan penyelesaian masalah. Dengan demikian, pertimbangan antropologi kesehatan merupakan organ vital dalam desain dan pengembangan peta jalan pembangunan kesehatan daerah dan nasional.

Alasan yang keempat yang Saya petakan muncul dari analisis subyektif perenungan pengalaman pribadi dan mungkin dialami oleh beberapa orang, bahwa kejadian penyakit tidaklah semata-mata berasal dari mikroorganisme patogen yang menyerang tubuh kita, akan tetapi bersumber dari tingkah laku kita sehari-hari dalam merespon pemenuhan kebutuhan. Bahwa jika dianalisis secara mendalam, sesungguhnya perilakulah yang menjadi sumber primer penyebab penyakit. Perilaku yang tidak sehat menyebabkan gampangnya kuman penyakit menghinggapi tubuh kita. Logika ini menegaskan bahwa kuman penyakit hanya berperan sebagai penyebab sekunder. Atau dengan kata lain, tidak ada kuman tanpa tubuh host yang rentan.

Pemaparan empiris di atas mengkonseptualisasikan suatu pemahaman tentang dimensi kejadian penyakit yang memiliki dua kutub yaitu kutub sosial dan kutub biologi. Penanggulangan masalah kesehatan yang memadukan kutub sosial dan kutub biologi mengindikasikan adanya pemikiran yang rasional dengan pola penanganan yang seimbang. Dominasi salah satu kutub dalam pelayanan kesehatan menyebabkan kepincangan/ketidakseimbangan, tentu saja bermuara pada kegagalan pembangunan kesehatan itu sendiri.

Keempat Justifikasi empiris di atas sejatinya menambah energitivitas kita dalam bertindak untuk segera keluar dari penjara kelaziman; kita butuh daya dorong dalam 
bentuk keberanian berinovasi, kita butuh untuk membangkitkan elan vital untuk akselerasi pembangunan kesehatan di Indonesia.

Untuk itu semua, maka pendekatan etnomedik bisa menjadi pintu masuk dalam memulai sesuatu yang nyata dan menerapkan eksperimentasi-ekperimentasi lapangan untuk menguji keterandalannya. Dalam konteks inipula, maka makalah ini akan mengekplorasi keterandalan pendekatan etnomedik dalam kultur masyarakat Bugis.

\section{Pondasi Nilai Sosial Budaya Masyarakat Bugis Sebagai Basis Pembentukan Konsep Sehat-Sakit}

Sebelumnya telah diklasifikasikan konsepsi etnomedik dijabarkan melalui proses interpretasi atau penafsiran masyarakat tentang konsep sehat sakit. Penafsiran adalah habitus yang terbentuk dalam sistim sosial budaya masyarakat. Untuk memahami secara tepat, mekanisme interpretasi sebagai habitus, maka dibutuhkan ekplorasi tentang nilai-nilai sosial budaya masyarakat bugis yang masih bertahan dan menjadi the spirit of life kehidupan komunitas. Tanpa falsafah ini, masyarakat bagaikan hidup terombang ambing di tengah lautan samudera luas; tanpa arah dan beresiko.

Beberapa falsafah nilai sosial budaya masyarakat bugis yang memiliki persentuhan dengan pembentukan konsep sehat sakit adalah nilai siri' na pacce yang bermakna adanya rasa malu terhadap tindakan-tindakan yang tidak baik, serta sangat peduli terhadap penderitaan sesama. Rasa malu dimanifestasikan sebagai harga diri bagi masyarakat bugis, sehingga apabila harga diri ini tersentuh, masyarakat bugis akan mempertahankannya sampai pun harus kehilangan nyawa. Sementara makna pacce melambangkan kepedulian sesama yang sangat tinggi, sehingga masyarakat bugis memiliki solidaritas yang kuat untuk saling membantu bagi yang membutuhkan.

Nilai siri na pacce memainkan peranan dalam sistim sosial yang menentukan cara masyarakat mendefinisikan penyakitnya. Masyarakat bugis merasa malu jika menderita penyakit-penyakit yang sudah diklaim oleh budaya dan mendapatkan stereotype sebagai penyakit kutukan, penyakit sosial, penyakit turun-temurun, dan penyakit yang harus dihindari secara sosial. Selain itu, kepedulian sesama telah menciptakan konsensus sosial dalam pengobatan melalui praktek-praktek supranatural yang memang sudah ada sejak dahulu kala.

Memahami nilai siri' na pacce pada masyarakat bugis dalam dunia kesehatan menghendaki adanya strategi pemaknaaan kembali tentang kesehatan. Jika selama ini yang ditonjolkan adalah konsepsi penyakit, maka perlu pemutarbalikan konsep menjadi penonjolan terhadap wacana kesehatan; bahwa status sehat anggota keluarga adalah bukti nyata hadirnya harga diri keluarga terhadap individu yang menjadi anggotanya.

Nilai sosial yang kedua yang biasanya dieksternalisasi oleh masyarakat bugis adalah resopa temmangingngi na malomo naletei pammase puang (Mahmud, 1986) yang artinya kerja keras terus menerus pantang menyerah akan berakhir dengan kesuksesan karena rahmat Allah SWT. Bagi masyarakat bugis, titian sukses melalui dua cara yang harus dilakukan secara simultan yaitu bekerja keras dan berdoa. 
Secara sosiologis, bekerja dan berdoa menandakan bekerjanya dua kesadaran yaitu kesadaran rasional dan kesadaran religious. Instrumen kesadaran ini memainkan perannya dan memberikan kontribusi yang berarti dalam membentuk cara pandang masyarakat terhadap konsep sehat sakit. Dengan menilik mekanisme operasi dua kesadaran ini, maka masyarakat bugis selalu menggabungkan dua cara pengobatan secara parallel yakni cara modern dan tradisional. Bahkan sub-kultur bugis tertentu seperti tolotang, to balo, lebih memberikan porsi yang besar terhadap pengobatan tradisional (Nismawati; Shermina Oruh; Andi Agustang, 2021)

Nilai sosial lainnya adalah tea temmakkua idi'pa najaji (Mattalitti, M. Arif, 1986) yang makna kulturalnya adalah tidak ada yang mampu mengubah nasib seseorang, kecuali orang yang bersangkutan atau dengan kata lain kesuksesan tergantung dari anda sendiri. Tersirat makna kemandirian bagi orang bugis untuk dapat melakukan apa saja dengan tujuan meraih keberhasilan. Ada inisiatif didalamnya, terkandung kreativitas dalam implementasinya, dan terdapat semangat keberanian untuk melangkah dimanapun berada (Andi Agustang, A, et al., 2021).

Dalam konteks sehat-sakit, nilai sosial tea temmakua idi'pa najaji memberikan pengaruh terhadap berkembangnya keberanian dalam menantang berbagai faktor resiko. Bagi komunitas ini, ancaman atau bahaya penyakit tidaklah dipandang sebagai hambatan dalam menjalani kehidupan, malah dianggap sebagai tantangan dalam menguji keberanian. Inilah yang menjelaskan teori-teori kesehatan seperti health belief model yang menekankan pada penilaian terhadap resiko, tidak memiliki power dalam landscap budaya bugis .

Nilai-nilai lainnya yang tidak sempat saya elaborasi secara mendalam dalam konteks kesehatan dan mempengaruhi pembentukan persepsi sehat-sakit masyarakat adalah sipakainge, sipakatau, sipakalabbi; taro ada taro gau; malilu sipakainge, mali siparappe, rebba sipatokkong (Agustang. A, 2011) (Punagi, 1983)

Refleksi atas peranan sistim sosial budaya masyarakat bugis terhadap pelayanan kesehatan membawa suatu nuansa baru untuk mengintegrasikan nilai-nilai ini dalam semua level pelayanan kesehatan, mulai tingkatan promosi kesehatan, pencegahan, kuratif, sampai pada tingkat pelayanan rehabilitative (Agustang \& Oruh, 2017). Dapat diproyeksikan, jika nilai sosial budaya dalam posisinya sebagai the spirit of life masyarakat digunakan sebagai pendekatan pelayanan kesehatan, maka partisipasi masyarakat untuk hidup sehat secara otomatis akan tumbuh dan berkembang.

\section{Internalisasi Etno-medik pada masyarakat bugis}

Masyarakat bugis sudah lama menginternalisasi nilai-nilai sosial budaya sebagai arahan kultural dalam tata pergaulan/interaksi pencegahan dan pengobatan penyakit. Sejumlah praktek kesehatan yang menjabarkan penerapan konsepsi etno-medik pada masyarakat bugis digambarkan berdasarkan faktor resiko yang terjadi pada manusia menurut siklus hidupnya.(Andi Agustang, 1999b)

Peristiwa kehamilan ibu menerapkan proses perawatan kehamilan yang diwarnai oleh praktek budaya yang diperankan dukun sebagai aktor utama. Seorang dukun 
menggunakan keahlian supranaturalnya dengan menggunakan "jampi-jampi" sebagai instrumen pengobatannya. Bagi masyarakat bugis, dukun bukan hanya sebagai ahli dalam merawat kehamilan, akan tetapi ia memiliki kekuatan luar biasa yang diperoleh secara turun menurun dari nenek moyangnya (Oruh et al., 2019) (Ambo Enre, Fachruddin, 1985). Kekuatan inilah yang membentuk kepercayaan dan keyakinan keluarga tentang pemanfaatan dukun sangat bremanfaat untuk menghasilkan keturunan yang sukses.

Proses kultural di atas juga terus berlangsung saat ibu mengalami persalinan, nifas dan perawatan anak, hingga tumbuh dan berkembang sebagai manusia dewasa yang mandiri (Oruh \& Agustang, 2019).

Ketika manusia mengalami gangguan kesehatan di masa hidupnya, ada asumsi antropologis yang dipercayai sebagai obat penyembuh yang mujarab yaitu praktek penggunaan ramuan dari tumbuh-tumbuhan tertentu sebagai hasil pengalaman panjang dialami oleh masyarakat. Katakanlah, daun jambu muda/biji untuk mengobati diare, daun srikaya dan mengkudu untuk terapi keseimbangan panasdingin melalui metode kompres, daun ota untuk menurunkan kolesterol darah, kumis kucing untuk memperlancar saluran kemih, dan lain-lain yang jumlah dan jenisnya begitu sangat banyak dan beragam (Andi Agustang, Agustang, et al., 2021).

Tidak sedikit masyarakat yang menggabungkan metode naturalistik di atas dengan metode supranaturalistik. Penerapan metode pengobatan masyarakat bugis, ada yang melakukannya secara sendiri dengan memanfaatkan pengetahuan dan pengalamnnya, dan adapula yang harus dibantu oleh seorang yang dianggap memiliki keahlian (baca dukun) (Agustang. A, 2011). Kategorisasinya tergantung dari jenis penyakit. Jika penyakitnya berupa gejala panas-dingin, biasanya diobati sendiri, namun jika gejala penyakit berkaitan dengan kelainan sistim syaraf harus mendapatkan pertolongan ahli, mengingat gejala ini dipersepsi adanya teguran dari arwah leluhur. Beberapa etnikpun menggunakan proposisi ini sebagai pijakan pengobatan penyakit (Andi Agustang, Tilome, et al., 2021).

Jenis penyakit yang sulit sembuh atau memunculkan gejala sakit yang berulangulang, acapkali dijustifikasi sebagai penyakit kultural yang pertolongannya menggunakan keahlian khusus. Biasanya, masyarakat menempuh jalur pengobatan tradisional-supranatural saat pertolongan medis sudah ditempuh, namun tidak memberikan hasil penyembuhan yang meyakinkan. Perilaku pencarian pengobatan seperti ini semakin hidup ditengah berkembangnya praktek pengobatan alternatif dengan berbagai metode terapi (Andi Agustang, Oruh, et al., 2021).

Internalisasi sistim nilai sosial budaya masyarakat dalam praktek pencegahan dan pengobatan penyakit menuntun diterapkannya praktek pelayanan kesehatan yang memadukan nilai-nilai tradisi dengan teknik-teknik pengobatan modern. Mau tidak mau, suka tidak suka, prototipe praktek tradisionalisme kesehatan mesti diadopsi oleh para provider, utamanya para pengambil kebijakan (Oruh et al., 2017).

\section{Etnomedik; Memadukan Kesehatan Tradisi Dan Kesehatan Modern}

Pengakuan terhadap efektivitas kesehatan tradisional sesungguhnya sudah diakomodasi dalam kebijakan pembangunan kesehatan dengan menjadikan kesehatan tradisional sebagai salah satu fungsi dalam struktur pemerintahan bidang 
Kesehatan (Akbar et al., 2021). Hanya saja fungsi ini tidak memberikan efek yang berarti ditengah maraknya upaya-upaya yang mendorong pemanfaatan layanan kesehatan modern .

Pelayanan kesehatan tradisional biasanya hanya menjadi wacana yang perlahanlahan digeser oleh dominasi kesehatan modern. Padahal realitas sosial masyarakat kita justru pola-pola pengobatan tradisional sudah menjadi kebiasaan dan bertransformasi menjadi suatu habitus (Andi Agustang, 2021b) .

Praktek terbaik yang bisa Saya sampaikan sebagai salah satu contoh pemaduan tradisi dan modern dalam bidang pelayanan kesehatan adalah kebijakan kemitraan bidan-dukun dalam praktek perawatan kehamilan dan pelayanan persalinan. Skema kemitraan ini paling tidak sudah merefleksikan adanya kesadaran utuh dalam mengintegrasikan nilai sosial budaya masyarakat pada proses pelayanan kesehatan, meskipun dalam beberapa sisi, kemitraan ini juga masih perlu dibedah secara kritis kaitannya dengan keadilan pembagian peran antara dukun dan bidan (Sumitro et al., 2021).

Gagasan-gagasan pemberdayaan masyarakat bidang kesehatan yang dituangkan dalam beberapa program-program nasional, dapat juga dinilai sebagai upaya pemaduan karena pemberdayaan masyarakat mensyaratkan adanya pemanfaatan nilai-nilai lokal dalam mendorong partisipasi masyarakat untuk hidup sehat (Andi Agustang, Oruh, et al., 2021). Area kritis yang bisa dimunculkan pada pendekatan pemberdayaan masyarakat adalah model-model intervensi yang kesannya antara memberdayakan atau memperdayai. Cukup banyak fakta dapat diamati di lapangan yang mengatasnamakan masyarakat sebagai subyek gerakan, padahal sesungguhnya masyarakat tetap berada dalam posisi obyek. Inklusi sosial petugas kesehatan merupakan tantangan tersendiri (Andi Agustang, 1999a).

Belajar dari sejumlah pengalaman tersebut, penerapan etnomedik dalam pelayanan kesehatan memerlukan intermediasi kolaboratif dengan organisasi-organisasi sosial kemasyarakatan yang memang memiliki kemampuan bidang pemberdayaan masyarakat (Oruh et al., 2017). Pemerintah hanyalah berperan sebagai regulator dan fasilitator, penggerakannya di lapangan harus dikawal oleh institusi sosialmasyarakat yang sudah mapan secara kultural. Dengan cara ini, wajah pembangunan kesehatan kita berubah menjadi wajah dengan pandangan optimistis menatap masa depan, insya Allah (Rasyid et al., 2021).

\section{Daftar Pustaka}

Agustang. A. (2011). Filosofi Research (Dalam Upaya Pengembangan Ilmu). Sarwah Press.

Agustang, A., \& Oruh, S. (2017). Factors affecting of heropnam of mental disorders in Dadi Regional Hospital in South Sulawesi Province. Man in India, 97(11), 233-244.

Agustang, A. (2021). Teknologi Partisipasi Metode Fasilitasi Pembuatan Keputusan Partisipatif. In OSF Preprints.

https://scholar.google.com/citations?view_op=view_citation\&hl=en\&user=el8HzI0AA AAJ\&pagesize $=100 \&$ citation_for_view=el8HzI0AAAAJ:6ZzL7HXColQC

Agustang, Andi. (1999a). INTERAKSI SOSIAL DAN PERUBAHAN STRUKTUR KOMUNITAS. Universitas Padjadjaran Bandung.

Agustang, Andi. (1999b). Interaksi Sosial dan Perubahan Struktur Komunitas (Studi Pada Masyarakat Kawasan Industri Makassar Sulawesi Selatan). 
Agustang, Andi. (2021a). \{IMPROVING $\}\{$ THE $\}\{$ QUALITY $\}\{O F\}\{$ PRIMARY\}

\{HEALTH $\}$ SSERVICES $\}\{$ IN\} \{THE\} \{PERSPECTIVE $\}\{$ OF $\}\{$ PARTICIPATORY\}

\{GOVERNANCE\}. https://doi.org/10.31219/osf.io/4kx6e

Agustang, Andi. (2021b). \{KERAJINAN\} \{TENUN\} \{PADA\} \{MASYARAKAT\} \{MUNA\}

(Kasus Peranan Modal Manusia dan Modal Sosial Dalam Reproduksi Budaya Tenun di Kabupaten Muna). https://doi.org/10.31219/osf.io/4bksf

Agustang, Andi, A, A. D. M. P., \& Asrifan, A. (2021). \{PERAN\} \{PENDIDIKAN\} $\{D A L A M\}\{M E M B A N G U N\}\{K A R A K T E R\}\{B A N G S A\}$. https://doi.org/10.31219/osf.io/na9pu

Agustang, Andi, Agustang, A. D. M. P., \& Agustang, A. (2021). Studi Politik Ekonomi Dalam Permulaan Wacana Development. https://doi.org/10.31219/osf.io/mx8gp

Agustang, Andi, \& Oruh, S. (2021). KESEJAHTERAAN PSIKOLOGIS (studi Pada Dewasa Madya Yang Belum Menikah Di Kota Makassar).

Agustang, Andi, Oruh, S., Agustang, A., \& Agustang, A. D. M. P. (2021). SOCIAL DETERMINANTS OF COMMUNITY HEALTH WITH THE EVENT OF DIABETES MELLITUS (Study of Health Sociology in Makassar City). https://doi.org/10.31219/osf.io/4qvxf

Agustang, Andi, Tilome, A. A., Agustang, A. D. M. P., \& Agustang, A. (2021). PERTUKARAN SOSIAL ELIT POLITIK DALAM PEMILIHAN KEPALA DAERAH DI PROVINSI GORONTALO. https://doi.org/10.31219/osf.io/6tu79

Akbar, H., Oruh, S., \& Agustang, A. (2021). Indeks Prediktif Kejadian Demam Berdarah Dengue (DBD) Berbasis Perilaku Sosial Masyarakat Di Kabupaten Indramayu. Jurnal Kesehatan, 14(2 SE-), 76-82. https://doi.org/10.32763/juke.v14i2.289

Asri, A., Kasnawi, T., \& Agustang, A. (2019). Actors' Social Tensions on Traditional Birth Attendants and Midwife Partnerships in Childbirth Assistance (Sociology of Health Study in Bulukumba Regency). IOSR Journal Of Humanities And Social Science (IOSR-JHSS), 24(Issue 1, Ser. 10), 20-27.

Nismawati; Shermina Oruh; Andi Agustang. (2021). Eksistensi Tari Kabasaran Pada Masyarakat Minahasa. Jurnal Ilmiah Mandala Education, 7(4), 194-198.

Oruh, S. (2021). Analisis faktor Keaktifan Kader dalam Kegiatan Posyandu. Jurnal Ilmiah Kesehatan Sandi Husada, 10(1), 319-325.

Oruh, S., \& Agustang, A. (2019). Pengaruh Pengetahuan Keluarga, Stigma Masyarakat dan Kepatuhan Minum Obat Terhadap Kekambuhan Penyakit Gangguan Jiwa di Kota Makassar. 53(9). https://doi.org/10.1017/CBO9781107415324.004

Oruh, S., Agustang, A., \& Alim, A. (2017). Kejadian Heropnam Gangguan Jiwa Dan Faktor Yang Mempengaruhi Pada Rumah Sakit Khusus Daerah Dadi Provinsi Sulawesi Selatan. July.

Oruh, S., Theresia, M., \& Agustang, A. (2019). KESEJAHTERAAN PSIKOLOGIS. Researchgate.Net.

Rasyid, D., Agustang, A., Syukur, M., Usman, S., \& Marzuki, M. (2021). Social transformation of indonesian older adults in suburbs: An exploratory-descriptive qualitative study. Studies on Ethno-Medicine, 15(1-2), 44-52. https://doi.org/10.31901/24566772.2021/15.1-2

Sumitro, S., Oruh, S., \& Agustang, A. (2021). Eksistensi Nilai Sosial Budaya Ndeu Paki Oi Mbaru Pada Masyarakat Donggo Kabupaten Bima. Jurnal Ilmiah Mandala Education, 7(4), 199-204. https://doi.org/10.36312/jime.v7i4.2432 